Creative commons User License: CC BY-NC-ND

Abstracted by: EBSCOhost, Electronic Journals Service (EJS),

Google Scholar, Directory of Open Access Journals (DOAJ),

Journal Seek, Scientific Commons,

Food and Agricultural Organization (FAO), CABI and Scopus
Journal of Agricultural Extension

Vol. 21 (1) February, 2017

ISSN(e): 24086851; ISSN(Print); 1119944X

http://journal.aesonnigeria.org

http://www.ajol.info/index.php/jae

Email: editorinchief@aesonnigeria.org

\title{
Institutional Factors Influencing Crop Farmers Adoption of Recommended Agrochemical Practices in Nigeria
}

http://dx.doi.org/10.4314/jae.v21i1.16

\author{
Issa, Fadlullah Olayiwola \\ National Agricultural Extension and Research Liaison Services (NAERLS), \\ Ahmadu Bello University, Zaria, Nigeria. \\ Email: issafola@gmail.com, +2348033339312
}

\section{Kagbu, Joyce Hauwa}

National Agricultural Extension and Research Liaison Services (NAERLS),

Ahmadu Bello University, Zaria, Nigeria.

Email: jkagbu@gmail.com +2348133344843

\begin{abstract}
This study examined the institutional factors influencing adoption of recommended agrochemical practices (RAPs) among crop farmers in Nigeria. A total of 260 crop farmers who have sustained the use of agrochemicals for at least five years were selected for the study using multi-stage sampling technique. Data were collected using pretested, structured interview schedule. Descriptive statistics (mean and percentages) and inferential statistics (multiple regression) were used for data analysis. The average number of extension visits to farmers was 5 per year. More than 50\% of crop farmers in Kaduna State were not visited in the last one year by extension agents. The majority (69.6\%) of the crop farmers had not received any training on the use of agrochemical since three years before the interview. Personal savings was the most major source of fund available to the majority of the crop farmers recording a weighted mean of 2.82 . The majority $(78.5 \%)$ received $\leq$ $\$ 100,000 / a n n u m$. Adoption of RAPs was positively and significantly influenced by degree of exposure to training. This study therefore, recommends that regular training on the use of agrochemical should be organized for farmers by extension agencies in collaboration with relevant stakeholders. Also, all forms of communication through the print and electronic media should be used by extension agencies in appealing to farmers to enhance adoption of RAPs.
\end{abstract}

Key words: Agrochemical practices, Adoption of crop protection.

\section{Introduction}

The use of agrochemical is very beneficial in crop production. Lomborg (2001) reports that if pesticides were abolished, the lives saved would be outnumbered by a factor of around 1000 by the lives lost due to poorer diets. Secondary penalties would be massive environmental damage due to the land needs of less productive farming, and a financial cost of around 20 billion US Dollars. Denis Avery (1999) Director of the 
Creative commons User License: CC BY-NC-ND

Abstracted by: EBSCOhost, Electronic Journals Service (EJS), Google Scholar, Directory of Open Access Journals (DOAJ), Journal Seek, Scientific Commons,

Food and Agricultural Organization (FAO), CABI and Scopus
Journal of Agricultural Extension

Vol. 21 (1) February, 2017

ISSN(e): 24086851; ISSN(Print); $1119944 X$

http://journal.aesonnigeria.org

http://www.ajol.info/index.php/jae

Email: editorinchief@aesonnigeria.org

Centre for Global Food Issues at the Hudson Institute in the US wrote in the Wall Street Journal that humanity in the 21st century cannot banish hunger and end nutritional deficits in its children without using chemicals and biotechnology to maintain and increase yields on land already under farming.

Agrochemicals are important agricultural inputs to protect crops from diseases, pests and weeds. The use of agrochemicals contributes not only to healthy growth of crops and animals but also to improved farm work efficiency and stable supply of tasty agricultural produce (Kughur (2012). Though 75\% of all herbicides in the world are used in developed countries, however, its use in developing countries is increasing (Nyatuame and Ampiaw, (2015), Food and Agricultural Organization and World Health Organization (2001).

Pests cost developing countries billions of dollars in national income (Food and Agriculture Organization [FAO], 2004) and farm and post-harvest losses contribute to hunger and malnutrition. Malnutrition kills between 12 million (United Nations Children Emergency Fund [UNICEF], undated) and 15 million children annually (Think Quest, 2005). According to Carol Bellamy, Executive Director of UNICEF, malnutrition is largely a silent and invisible emergency, exacting a terrible toll on children and their families. It would neither be logical nor ethical to expect poor people to forego the benefits of technologies used in the richer countries to grow and protect crops.

There is widespread recognition that farmers misuse agrochemicals while protecting crops from incidences of pests and diseases. High incidence of pesticide failure and unprecedented level of pesticides related accidents and their attendant consequences on the health of people is quite alarming (FAO, 1998). Exposure to agrochemicals poses an increasing health risk in agricultural work especially as pesticide sales and use have continued to rise over the years thereby increasing farmers' risks due to the increasing use of more toxic chemicals. The International Labour Organization (ILO) and FAO (2012) assert that 170,000 of the 335,000 fatal workplace accidents that occur annually worldwide involved agricultural workers thereby making agriculture one of the three most dangerous sector to work, along with construction and mining. 
Creative commons User License: CC BY-NC-ND

Abstracted by: EBSCOhost, Electronic Journals Service (EJS), Google Scholar, Directory of Open Access Journals (DOAJ), Journal Seek, Scientific Commons,

Food and Agricultural Organization (FAO), CABI and Scopus
Journal of Agricultural Extension

Vol. 21 (1) February, 2017

ISSN(e): 24086851; ISSN(Print); $1119944 X$

http://journal.aesonnigeria.org

http://www.ajol.info/index.php/jae

Email: editorinchief@aesonnigeria.org

Furthermore, available literature (Zyoud et al., 2010) as well as field experiences from various practitioners indicate a demand-supply system that just emerged by chance, hence not perfect but characterized by adulteration, use of expired chemicals as well as inefficiency in usage, improper storage, bad (high) retailing prices, and lack of safety measures (FAO, 1998). Already, useful amount of work has been done by research institutes and extension agencies in providing information on researchbased recommended agrochemical practices (RAPs) (Laary, 2012; Zyoud et al., 2010; Asogwa and Dango, 2009; Kishi, 2005; and Kishi et al., 2005). Despite these efforts, cases of environmental and health hazards resulting from misuse of agrochemicals abound. Persistent incidences of agrochemical-related accidents are worrisome (Abdullahi, 2008). Importantly, data on how recommended agrochemical practices are being adopted by farmers in Nigeria is very scanty. Safety and health in the use of agrochemicals has been one of the primary concerns of international organizations and of many governments for over two decades.

With this background therefore, the need for a systematic investigation of the adoption of available recommended agrochemical practices and problems associated with their adoption has become imperative (Abdullahi, 2008). Illegal trade in pesticides is a significant global problem. In developing countries, as much as $30 \%$ of the pesticides do not meet internationally recognized safety standards (Vaagt, 2005). The most striking significance of this study is that, an x-ray of literature (FAO, 1998; Meijden, 1998; Udoh, 2009; Ecobichon, 2001; Dugje et al., 2008; Asogwa and Dango, 2009; Mokwunye et al., 2012) on the use of crop protection chemicals in Nigeria indicated that very few studies have evaluated how adoption of recommended agrochemical practices were adopted by farmers and the institutional factors influencing it.

The broad objective of this study was to determine the institutional factors influencing farmers' adoption of recommended agrochemical practices in Nigeria. Specific objectives of the study were to:

i. assess the sources of information on agrochemicals;

ii. assess the extension visits to crop farmers; 
Creative commons User License: CC BY-NC-ND

Abstracted by: EBSCOhost, Electronic Journals Service (EJS),

Google Scholar, Directory of Open Access Journals (DOAJ),

Journal Seek, Scientific Commons,

Food and Agricultural Organization (FAO), CABI and Scopus
Journal of Agricultural Extension

Vol. 21 (1) February, 2017

ISSN(e): 24086851; ISSN(Print); 1119944X

http://journal.aesonnigeria.org

http://www.ajol.info/index.php/iae

Email: editorinchief@aesonnigeria.org

iii. examine the agrochemical-related training received by farmers and

iv. examine the major sources of credit available to crop farmers.

\section{Methodology}

This study was carried out in Kaduna and Ondo States from the Northern and Southern Nigeria, respectively. Kaduna State lies between longitude $06^{\prime} 00$ and $09^{\prime} 10^{\prime}$ East of the Greenwich meridian and between latitudes $09^{\circ} 00$ and $11^{0} 30$ north of the Equator. Kaduna State occupies an area of approximately 48,473.2 square kilometers (Federal Office of Statistics (FOS), 2006). Kaduna State has 23 Local Government Areas and its population was put at 6, 066, 526 people (National population Commission [NPC], 2006) and had a projected population of 7, 813, 685 people in 2015 using an annual growth rate of $3.2 \%$. Ondo State lies between latitudes $5^{\circ} 45^{\prime}$ and $7^{\circ} 52^{\prime} \mathrm{N}$ and longitudes $4^{\circ} 20^{\prime}$ and $6^{\circ} 05^{\prime} \mathrm{E}$. Its land area is about 15,500 square kilometers. Ondo State has 18 Local Government Areas and its population was put at $3,460,877$ people (NPC, 2006) and had a projected population of 4, 457, 609 people in 2015 using an annual growth rate of $3.2 \%$. A wide range of fungicides are available in Ondo State (Olabode, Adesina, and Olapeju, 2011) due to heavy use of fungicides associated with cocoa production.

This study focused on crop farmers who had been using agrochemicals for at least five years in Kaduna and Ondo States of Nigeria. The selection of these states was based on high volume of use of agrochemical as reported by NAERLS and NPAFS (2011). The estimated volume of pesticide use in Kaduna was 198,550 liters while 344,429 liters was consumed in Ondo State making the two States the highest consumer of agrochemicals in Nigeria. Multi-stage sampling technique was employed in selecting the farmers. Stages one and two were purposive selections of two agricultural zones of ADPs per state; and 2 blocks per zone, respectively. The criterion for the purposive selections was the high intensity of agrochemical use based on the record of the ADPs. The third stage involved the purposive selection of two villages per block. Lastly, the fourth stage involved using the list of farmers obtained from the reconnaissance survey (conducted by the researcher between $2^{\text {nd }}$ and $9^{\text {th }}$ September, 2013) to randomly select $15 \%$ of farmers from each of the eight 
Creative commons User License: CC BY-NC-ND

Abstracted by: EBSCOhost, Electronic Journals Service (EJS),

Google Scholar, Directory of Open Access Journals (DOAJ),

Journal Seek, Scientific Commons,

Food and Agricultural Organization (FAO), CABI and Scopus
Journal of Agricultural Extension

Vol. 21 (1) February, 2017

ISSN(e): 24086851; ISSN(Print); $1119944 X$

http://journal.aesonnigeria.org

http://www.ajol.info/index.php/jae

Email: editorinchief@aesonnigeria.org

villages. In all, a total of 135 and 125 crop farmers were selected from Kaduna and Ondo State, respectively and a total of 260 crop farmers.

Data for the study were collected with the use of pre-tested, structured interview schedule administered on farmers. Farmers were visited to conduct on-the-spot interview. Data collection exercise was conducted between $26^{\text {th }}$ August and $29^{\text {th }}$ September, 2014. Trained enumerators were used for data collection.

Multiple regression techniques was used to estimate the relationship between institutional factors and the level of adoption of RAPs. Multiple regression was determined using:

$Y=a_{0}+b_{1} x_{1}+b_{2} x_{2}+b_{3} x_{3} \ldots \ldots \ldots \ldots \ldots \ldots \ldots \ldots b_{5} x_{5}+e$

Where:

$\mathrm{Y}=$ Level of adoption (Total number of RAPs adopted)

$\mathrm{X}_{1}=$ Extension contact (Number of extension visits enjoyed per year)

$X_{2}=$ Access to information (Number of sources accessible to crop farmers)

$\mathrm{X}_{3}=$ Access to training (number of trainings attended in the last 5 years)

$\mathrm{X}_{4}=$ Sources of agrochemicals (number of sources available to crop farmers)

$\mathrm{X}_{5}=$ Access to credit (amount in Naira)

$\mathrm{a}=$ Constant term

$\mathrm{e}=$ Error terms

It was hypothesized that there was no significant relationship between institutional factors and the level of adoption of RAPs.

\section{Results and Discussion}

\section{Crop Farmers' Sources of Agrochemical Information}

Other farmers (95.4\%), the ADPs (93.1\%) and radio (89.6\%) were indicated as the most useful source of information about RAPs to farmers (Table 1). This implies that sources of information to farmers with respect to recommended agrochemical practices are highly informal. The ranking shows that least information on recommended agrochemical practices obtained by farmers through Environmental Protection Agency (13.8\%). Nonetheless, farmers frequently suggest that other 
Creative commons User License: CC BY-NC-ND

Abstracted by: EBSCOhost, Electronic Journals Service (EJS),

Google Scholar, Directory of Open Access Journals (DOAJ),

Journal Seek, Scientific Commons,

Food and Agricultural Organization (FAO), CABI and Scopus
Journal of Agricultural Extension

Vol. 21 (1) February, 2017

ISSN(e): 24086851; ISSN(Print); 1119944X

http://journal.aesonnigeria.org

http://www.ajol.info/index.php/jae

Email: editorinchief@aesonnigeria.org

farmers were an important source of information about farming. According to Baral et al. (2006) neighbors and relatives were valued sources of information in India, but extension agents and radio broadcasts were not. This situation is identical to what is happening in neighboring Bangladesh (Rashid et al., 2003) and in other states of India (Alam et al., 2006) where informal sources were more useful as source of information about farming.

Table 1: Distribution of crop farmers based on sources of information

\begin{tabular}{lcc}
\hline & Usefulness & \\
\cline { 2 - 3 } Sources of information & Number of crop farmers & Rank \\
\hline Other farmers & $248(95.4)$ & $1^{\text {st }}$ \\
ADPs & $242(93.1)$ & $2^{\text {nd }}$ \\
Radio & $233(89.6)$ & $3^{\text {rd }}$ \\
Input dealers & $230(88.5)$ & $4^{\text {th }}$ \\
Research institutes & $219(84.2)$ & $5^{\text {th }}$ \\
Village head & $188(72.3)$ & $6^{\text {th }}$ \\
Agric Show & $188(72.3)$ & $6^{\text {th }}$ \\
Cooperatives & $174(66.9)$ & $7^{\text {th }}$ \\
Television & $157(60.4)$ & $8^{\text {th }}$ \\
Newspaper & $124(47.7)$ & $9^{\text {th }}$ \\
Internet & $105(40.4)$ & $10^{\text {th }}$ \\
NAFDAC & $88(32.3)$ & $11^{\text {th }}$ \\
EPA & $36(13.8)$ & $12^{\text {th }}$ \\
\hline
\end{tabular}

\section{Extension Visits to Crop Farmers}

More than $30 \%$ of crop farmers were not visited in the last one year while about half $(50.7 \%)$ were visited $1-8$ times in a year by extension agents (Table 2 ). Further breakdown indicates that the EA:farmer ratio in Ondo State $(1: 1480)$ is less than what was obtained in Kaduna State. Farmers in Ondo State seem to enjoy more extension visits $(\bar{x}=6)$ compared to farmers in Kaduna State $(\bar{x}$ 
Creative commons User License: CC BY-NC-ND

Abstracted by: EBSCOhost, Electronic Journals Service (EJS), Google Scholar, Directory of Open Access Journals (DOAJ), Journal Seek, Scientific Commons,

Food and Agricultural Organization (FAO), CABI and Scopus
Journal of Agricultural Extension

Vol. 21 (1) February, 2017

ISSN(e): 24086851; ISSN(Print); $1119944 X$

http://journal.aesonnigeria.org

http://www.ajol.info/index.php/jae

Email: editorinchief@aesonnigeria.org

=4). However, this result negates the report of NAERLS and Federal Department of Agricultural Extension [FDAE] (2014) which revealed that extension visit to farmers increased by $18 \%$ from 2013 to 2014 in Kaduna State where the EA:farmer ratio was $1: 3704$. It must be noted that Kaduna State operated with just $26 \%$ of the required VEA workforce in 2013 and 2014 having only 161 VEAs out of the required 606 VEAs. In Ondo State, the number of VEAs declined by about $10 \%$ between 2013 and 2014. That farmers in Ondo State enjoy more extension visit compared to their Kaduna State counterparts negates apriori expectation due to the fact that there are more agricultural research institutions in Kaduna State compared to Ondo (Idachaba, 1980).

Table 2: Distribution of crop farmers according to number of extension visits

\begin{tabular}{llc}
\hline Number of extension visits per year & Number of farmers & Mean \\
\hline 0 & $80(30.7)$ & 5 \\
$1-8$ & $132(50.7)$ & \\
$9-16$ & $45(17.3)$ \\
Above 16 & $3(1.2)$ \\
\hline
\end{tabular}

Extension contact with farmers enhances acquisition of new knowledge, skill and practices on improved technology by the farmers as well as their innovativeness (Tanko and Olowogbaji 2009) which is expected to translate into increased adoption of RAPs. Contacts with extension agents afford the farmers the opportunity of sharing ideas and information on modern rice production practices by interacting with other farmers. This suggests that the extension services are not adequate in the survey area given the recommended extension agent to farmer ratio. Importantly, inadequate funding and staffing, inadequate staff training and poor mobility were the major problems of ADPs across the country (NAERLS and FDAE, 2014).

\section{Agrochemical-related Training Received by Crop Farmers}

The majority (69.6\%) of the crop farmers had not received any training on the use of agrochemical since three years before the interview (Table 3). Training is an added input which enhances good performance and adoption (Meenambigai and Seetharaman, 2003). This result agrees with the findings of Meijden (1998) that farmers were not exposed to training in the use of agrochemical. Also, this result negates the findings of NAERLS and FDAE (2014) that extension visit to farmers 
Creative commons User License: CC BY-NC-ND

Abstracted by: EBSCOhost, Electronic Journals Service (EJS), Google Scholar, Directory of Open Access Journals (DOAJ), Journal Seek, Scientific Commons,

Food and Agricultural Organization (FAO), CABI and Scopus
Journal of Agricultural Extension

Vol. 21 (1) February, 2017

ISSN(e): 24086851; ISSN(Print); $1119944 X$

http://journal.aesonnigeria.org

http://www.ajol.info/index.php/jae

Email: editorinchief@aesonnigeria.org

increased by $18 \%$ between 2013 and 2014 in Kaduna State where the number of forth-nightly trainings (FNTs) conducted declined by $8 \%$ within the same period.

Training makes a trainee more knowledgeable and efficient. It is important to build the capacity of the farmer more profoundly. When a farmer attends more training organized by extension agency or any other relevant institution, he/she will be more acquainted with the activities of this institution as well as gathered more knowledge regarding new agricultural practices with skill. So, training is the means through which the farmer can equip themselves with the latest knowledge regarding agrochemical practices.

The majority (53.2, and 52.9\%) of those crop farmers who received training on agrochemicals were trained just one time in application techniques and safety precautions respectively. In a study carried out in Ethiopia; Amera and Abate (2008) found that only 12.1 and $12.5 \%$ of crop farmers received training on health and safety, and application techniques respectively while only $7.1 \%$ of them received training on IPM. Generally, most of the trainings were organized by the NGOs as indicated by the majority (54.4\%) (Table 3). Dugje et al. (2008) found that many pesticide users lack awareness and technical training. 
Creative commons User License: CC BY-NC-ND

Abstracted by: EBSCOhost, Electronic Journals Service (EJS),

Google Scholar, Directory of Open Access Journals (DOAJ),

Journal Seek, Scientific Commons,

Food and Agricultural Organization (FAO), CABI and Scopus
Journal of Agricultural Extension

Vol. 21 (1) February, 2017

ISSN(e): 24086851; ISSN(Print); 1119944X

http://journal.aesonnigeria.org

http://www.ajol.info/index.php/jae

Email: editorinchief@aesonnigeria.org

Table 3: Distribution of crop farmers by number of times trained, and the organizer*

\begin{tabular}{|c|c|c|c|}
\hline \multirow[t]{2}{*}{ Variables } & \multicolumn{3}{|c|}{ Types of Training } \\
\hline & $\begin{array}{c}\text { Application } \\
\text { techniques }(n=79)\end{array}$ & $\begin{array}{c}\text { Health and } \\
\text { safety }(n=63)\end{array}$ & $\begin{array}{l}\text { I P M } \\
(n=68)\end{array}$ \\
\hline \multicolumn{4}{|c|}{ Number of times trained } \\
\hline $1-2$ & $72(91.1)$ & 55 (87.3) & $64(94.1)$ \\
\hline $3-4$ & $7(8.9)$ & $8(12.7)$ & $4(5.9)$ \\
\hline \multicolumn{4}{|l|}{ Organizers $^{*}(n=79)$} \\
\hline ADPs & $42(53.2)$ & $15(23.8)$ & $15(22.1)$ \\
\hline Input trader/dealer & $21(26.6)$ & $17(26.9)$ & $6(8.8)$ \\
\hline Research Institutes & 0 & $4(6.3)$ & 0 \\
\hline NGOs & $43(54.4)$ & $33(52.4)$ & $24(35.3)$ \\
\hline LGAs & 0 & $18(28.6)$ & $18(24.5)$ \\
\hline Producer/distributor & $4(5.1)$ & 0 & 0 \\
\hline Cooperatives & 0 & $1(1.6)$ & $1(1.5)$ \\
\hline $\begin{array}{l}\text { Ministry of } \\
\text { Agriculture }\end{array}$ & 0 & 0 & 0 \\
\hline International Agency & 0 & 0 & 0 \\
\hline
\end{tabular}

${ }^{*}$ Multiple responses

Figures in parentheses are percentages

\section{Major Sources of Credit Available to Crop Farmers}

Personal savings was the most major source of fund available to the majority of the crop farmers recording a weighted mean of 2.82 (Table 4). This result clearly depicts that farmers heavily rely on informal (non-conventional) sources to fund for their farming activities. This may be due to dysfunctionality of government credit institutions or the stringent conditions attached to loan procurement. Such conditions include high interest rate, low moratorium, and high collateral. 
Creative commons User License: CC BY-NC-ND

Abstracted by: EBSCOhost, Electronic Journals Service (EJS),

Google Scholar, Directory of Open Access Journals (DOAJ),

Journal Seek, Scientific Commons,

Food and Agricultural Organization (FAO), CABI and Scopus
Journal of Agricultural Extension

Vol. 21 (1) February, 2017

ISSN(e): 24086851; ISSN(Print); 1119944X

http://journal.aesonnigeria.org

http://www.ajol.info/index.php/jae

Email: editorinchief@aesonnigeria.org

Table 4: Distribution of crop farmers according to major sources of credit*

\begin{tabular}{|c|c|c|c|c|c|c|}
\hline \multirow[t]{2}{*}{ Sources of Credit } & \multicolumn{3}{|c|}{ Weighted Scores } & \multirow{2}{*}{$\begin{array}{l}\text { Weight } \\
\text { ed Sum }\end{array}$} & \multirow{2}{*}{$\begin{array}{l}\text { Weighted } \\
\text { Mean }\end{array}$} & \multirow[t]{2}{*}{ Rank } \\
\hline & Very Major & Major & Not Major & & & \\
\hline $\begin{array}{l}\text { Financial } \\
\text { institutions }\end{array}$ & 3 & 50 & 234 & 287 & $1.11^{*}$ & $7^{\text {th }}$ \\
\hline NGOs & 78 & 100 & 184 & 362 & $1.28^{*}$ & $4^{\text {th }}$ \\
\hline Input traders & 57 & 60 & 211 & 328 & $1.27^{*}$ & $5^{\text {th }}$ \\
\hline \multicolumn{7}{|l|}{ Government } \\
\hline Relatives/friends & 174 & 48 & 178 & 400 & $1.55^{\star}$ & $2^{\text {nd }}$ \\
\hline Farmers' groups & 132 & 68 & 182 & 382 & $1.48^{*}$ & $3^{\text {rd }}$ \\
\hline Personal savings & 672 & 50 & 11 & 733 & $2.82^{* \star *}$ & $1^{\text {st }}$ \\
\hline \multicolumn{4}{|c|}{ Weighted Mean Average } & & 1.54 & \\
\hline
\end{tabular}

${ }^{* \star *}$ Very Major, ${ }^{* \star}$ Major, ${ }^{\star}$ Not Major

${ }^{*}$ Multiple responses

\section{Amount of Credit Received by Crop Farmers}

Result in Table 5 revealed that the majority (78.5\%) of the crop farmers got equal or less than $\$ 100,000$. Credit use is expected to assist farmers purchase necessary inputs for crop production. However, many sources of credit nowadays, give the farmer more chances of securing improved inputs rather than given cash. The mean amount of credit received by crop farmers in the last one year was $\$ 72,798$. Rahman (2008) found similar result that most farmers receive little or no credit to operate their farms.

Table 5: Distribution of crop farmers based on amount of credit received in one year

\begin{tabular}{lll}
\hline Amount of Credit Received (\$) & Frequency (\%) & \multicolumn{1}{c}{ Mean } \\
\hline$\leq 100,000$ & $204(78.5)$ & 72,798 \\
$101,000-200,000$ & $28(10.8)$ & \\
$210,000-300,000$ & $11(4.2)$ & \\
$301,000-400,000$ & $9(3.5)$ & \\
$401,000-500,000$ & $5(1.9)$ & \\
$>500,000$ & $4(1.5)$ & \\
\hline
\end{tabular}

Figures in parentheses are percentages 
Creative commons User License: CC BY-NC-ND

Abstracted by: EBSCOhost, Electronic Journals Service (EJS), Google Scholar, Directory of Open Access Journals (DOAJ), Journal Seek, Scientific Commons,

Food and Agricultural Organization (FAO), CABI and Scopus
Journal of Agricultural Extension

Vol. 21 (1) February, 2017

ISSN(e): 24086851; ISSN(Print); $1119944 X$

http://journal.aesonnigeria.org

http://www.ajol.info/index.php/jae

Email: editorinchief@aesonnigeria.org

\section{Institutional Factors Influencing Adoption of RAPs}

It was hypothesized that there is no significant relationship between institutional variables and adoption of RAPs. Access to training $(0.157, \mathrm{P}<0.01)$ and accessibility of agrochemicals $(0.101, \mathrm{P}<0.10)$ were found to significantly influence adoption of RAPs (Table 6). These variables were strong determinants of adoption of RAPs among crop farmers. Therefore, contrary to the stated null hypothesis; institutional variables significantly influenced adoption of RAPs. Hence, the null hypothesis was rejected. The adjusted $R^{2}$ was 0.59 . This implies that $59 \%$ of the variations in the adoption of RAPs were contributed by the independent variables specified in the model.

Training received was also found to significantly influence adoption of RAPs $(0.157$, $P<0.01)$. This result was expected as a well-trained farmer would likely understand the rudiments of using agrochemicals as well as the recommended practices. The probability of adoption of RAPs given adequate and regular formal training was 59 percent, making this factor the greatest institutional driver of RAPs' adoption. This result implies that a unit increase in the number of training on agrochemical usage offered to farmers will bring about 59 percent increases in adoption of RAPs.

Table 6: Institutional factors influencing adoption of Recommended Agrochemical Practices in Kaduna and Ondo States

\begin{tabular}{lccc}
\hline Variables & Coef & Std error & $\mathbf{Z}$ \\
\hline Extension visit & 0.002 & 0.003 & 0.80 \\
Access to information & 0.001 & 0.002 & 0.75 \\
Training on agrochemicals & 0.157 & 0.035 & $2.48^{\star \star \star}$ \\
Access to agrochemicals & 0.101 & 0.038 & $1.99^{\star}$ \\
Credit received & 0.462 & 0.373 & 0.39 \\
$\mathrm{R}^{2}$ & 0.552 & & \\
Adjusted $\mathrm{R}^{2}$ & 0.587 & & \\
${ }^{* * *} \mathrm{P} \leq 0.01$ & & & \\
${ }^{* *} \mathrm{P} \leq 0.05$ & & & \\
${ }^{*} \mathrm{P} \leq 0.1$ & & & \\
\hline
\end{tabular}


Creative commons User License: CC BY-NC-ND

Abstracted by: EBSCOhost, Electronic Journals Service (EJS), Google Scholar, Directory of Open Access Journals (DOAJ), Journal Seek, Scientific Commons,

Food and Agricultural Organization (FAO), CABI and Scopus
Journal of Agricultural Extension

Vol. 21 (1) February, 2017

ISSN(e): 24086851; ISSN(Print); $1119944 X$

http://journal.aesonnigeria.org

http://www.ajol.info/index.php/jae

Email: editorinchief@aesonnigeria.org

Farmers' training and knowledge help in proper use of pesticides (Mariyono and Bhattarai, 2010). It is important to know that this study assessed the formal training received by farmer (outside the routine extension visit). The findings of this study are consistent with that of Abdulai and Binder (2006); and Moser and Barrett (2003) who found a positive and statistically significant relationship between adoption and having access to formal training. This finding of this study suggests that regular formal training is important in any efforts aimed at encouraging adoption of RAPs in the study area.

Another reason that may explain this result is that farmers with access to training also had opportunity to spraying equipment, and such farmers try to be a good example to others. The effect of farmer linkages with formal training suggests that linkages between farmers and holders of agrochemical practices (including knowledge, techniques and the agrochemicals) are important.

Extension visit was found to be positive but non-significantly related with adoption of RAPs. This may be counter-intuitive. Extension contact with farmers enhance acquisition of new knowledge, skill and practices on improved technology by the farmers as well as their innovativeness (Dey et al., 2000; Tanko and Olowogbaji 2009) which is expected to translate into increased technology adoption and increased outputs. Contacts with extension agents afford the farmers the opportunity of sharing ideas and information on recommended practices through interaction with other farmers. The finding of this study is consistent with earlier results by Enwerem and Ohajianya (2013) who found a positive but non-significant relationship between technology adoption and extension contact. This suggests that the extension services are not adequate in the survey area given the recommended extension agent to farmer ratio. More so, farmers were visited only 5 times in the previous year (Table 2). Furthermore, Meijden (1998) noted that extensionists are generally trained more on which pesticides should be used for which pest rather than on the equipment and application techniques. He added that, for the fact that extension workers are not always available (may be due to high extension agent: farm family ratio) for advice, the farmers rely on pesticide vendors and product labels for information on how to apply the pesticides and the safety precautions. The major producers and distributors of pesticides in Nigeria have in most cases not taken responsibility to provide training 
Creative commons User License: CC BY-NC-ND

Abstracted by: EBSCOhost, Electronic Journals Service (EJS),

Google Scholar, Directory of Open Access Journals (DOAJ),

Journal Seek, Scientific Commons,

Food and Agricultural Organization (FAO), CABI and Scopus
Journal of Agricultural Extension

Vol. 21 (1) February, 2017

ISSN(e): 24086851; ISSN(Print); 1119944X

http://journal.aesonnigeria.org

http://www.ajol.info/index.php/jae

Email: editorinchief@aesonnigeria.org

for their retailers to enable them assist the end users with precautionary measures (Asogwa and Dongo, 2009). Jamilu et al. (2016) and Namwata et al. (2010) reported that increased extension contact was positively and significantly associated with overall adoption of improved agricultural technologies among farmers.

Meanwhile, apart from cases of non-visitation by extension agents to farmers, there also exist cases of extension visitation without effective delivery. This might be due to low competency on the part of the extension agent, or due to inadequate teaching aids, among other possible reasons. Adedoyin (1996) and Issa (2006) advocated that extension agents' visits must be essentially purposeful (for efficient delivery) in order to be effective.

\section{Conclusion and Recommendations}

Most farmers were not exposed to practical training on RAPs. Also, farmers rarely visited by extension agents. In the same vein, farmers' access to formal source of credit was poor.

Exposure to formal training in the use of agrochemical was found to be positively significant with adoption of RAPs. To this end, Stakeholders (government extension services, EPA, NAFDAC, input dealers, FBOs and NGO) should collaborate to support and facilitate proper and regular training of farmers on RAPs. Regular training of farmers should practically emphasize application techniques, as well as personal health and safety measures. Such training should take full advantage of farmers'based organizations. More so, the majority of the few farmers who received training on the use of agrochemical were trained by NGOs or private organizations. It is therefore, logical for government to reform existing extension service of the ADPs such that it would have the capacity to train farmers on the application techniques of agrochemicals. This can be achieved through collaboration with private organizations. Due to poor visitation by extension agents, all forms of communication through the print and electronic media should be used by extension agencies in appealing to farmers to enhance their positive attitude for embracing the adoption of RAPs. 
Creative commons User License: CC BY-NC-ND

Abstracted by: EBSCOhost, Electronic Journals Service (EJS),

Google Scholar, Directory of Open Access Journals (DOAJ),

Journal Seek, Scientific Commons,

Food and Agricultural Organization (FAO), CABI and Scopus
Journal of Agricultural Extension

Vol. 21 (1) February, 2017

ISSN(e): 24086851; ISSN(Print); $1119944 X$

http://journal.aesonnigeria.org

http://www.ajol.info/index.php/jae

Email: editorinchief@aesonnigeria.org

\section{References}

Abdulai, A.C, and Binder, C. (2006). Slash and burn cultivation practice and agricultural input demand and output supply. Journal of Environment and Development Economics, 11(2): 201-220.

Abdullahi, S. U. (2008). The Vice Chancellor's opening remarks delivered at the National Workshop on pesticide usage, handling and safety procedures held at NAERLS conference hall, Ahmadu Bello University, Zaria on $18^{\text {th }}$ November.

Adedoyin, S. F. (1996). Extension visits and technology delivery. Paper presented at the 1996 pre-season training of field staff of Lagos State Agricultural Development Authority held at CAPL Training School, Ikeja between $3^{\text {rd }}$ and $11^{\text {th }}$ March.

Alam, S.N., Hossain, M. I., Rouf, F.M.A., Jhala, R.C., Patel, M.G., Rath, L.K., Sengupta, A., Baral, K., Shylesha, A. N., Satpathy, S., Shivalingaswamy, T.M., Cork, A. and Talekar, N.S. (2006). Implementation and promotion of IPM strategy for eggplant fruit and shoot borer in South Asia. Technical Bulletin 36. AVRDC - The World Vegetable Center, Shanhua, Taiwan. 74 pp.

Amera, T. and Abate, A. (2008). An assessment of the pesticide use, practice and hazards in the Ethiopian Rift Valley. Africa Stockpiles Programme, Annex 6. Pp 61.

Asogwa, E.U. and Dango, L.N. (2009). Problems associated with pesticide usage and application in Nigerian cocoa production: A review.African Journal of Agricultural Research Vol. 4 (8), pp. 675-683, August. Retrieved from http://www.academicjournals.org/AJAR Assessed: 13/04/2012.

Baral, K., Roy, B.C., Rahim, K.M.B., Chatterjee, H., Mondal, P., Mondal, D., Ghosh, D. and Talekar, N.S. (2006). Socio-economic parameters of pesticide use and assessment of impact of an IPM strategy for the control of eggplant fruit and shoot borer in West Bengal, India. Technical Bulletin No. 37.AVRDC - The World Vegetable Center, Shanhua, Taiwan.36 pp.

Dey, M. M, Paragnas, G. B and Regaspi, P. B (2000). Technical Efficiency of Tilapia growth out of pornd operation in the Phillippines. Aquaculture, economics and management. 4 (2): 33-46.

Dugje, I. Y., Ekeleme, F., Kamara, A. Y., Omoigui, L. O., Tegbaru, A., Teli, I. A. and Onyibe, J. E. (2008). Guide to safe and effective use of pesticides for crop production in Borno State, Nigeria. 23 pp.

Ecobichon, D. J. (2001). Pesticide Use in Developing Countries, Toxicology. 160, 2733 
Creative commons User License: CC BY-NC-ND

Abstracted by: EBSCOhost, Electronic Journals Service (EJS),

Google Scholar, Directory of Open Access Journals (DOAJ),

Journal Seek, Scientific Commons,

Food and Agricultural Organization (FAO), CABI and Scopus
Journal of Agricultural Extension

Vol. 21 (1) February, 2017

ISSN(e): 24086851; ISSN(Print); 1119944X

http://journal.aesonnigeria.org

http://www.ajol.info/index.php/jae

Email: editorinchief@aesonnigeria.org

Enwerem, V.A.1 and Ohajianya, D.O. (2013). Farm size and technical efficiency of rice farmers in Imo State, Nigeria. Greener Journal of Agricultural Sciences,3(2), pp. 128-136.

Federal Office of Statistics (2006). Annual Abstract of Statistics. Federal Office of Statistics,Abuja.

Food and Agricultural Organization (FAO) (1998).Pesticide application techniques in West-Africa.Pp 13.

Food and Agricultural Organization (FAO) (2004). The state of food insecurity in the World 2004. Economic and Social Department, Food and Agriculture Organization of the United Nations, Rome.

Food and Agricultural Organization and World Health Organization (2001). Amount of poor-quality pesticides sold in developing countries alarmingly high. Press Release, 1st February, 2001. Rome.

Idachaba, F. S. (1980) Agricultural research policy in Nigeria. Research Report 17. International Food Policy Research Institute. August. Pp 73.

International Labour Organization (ILO) and Food and Agriculture Organization (2012). Food, agriculture and decent work: Safety and health. Available at: wwwfao-ilo.org/more/fao-ilo-safety/en/ Assessed 24 ${ }^{\text {th }}$ March, 2015.

Issa, F. O. (2006). On-Farm Adaptive Research and Small Plot Adoption Technique as strategies for agricultural technology delivery in Lagos State. Proceedings of $11^{\text {th }}$ Annual Conference of Agricultural Extension Society of Nigeria. Held at University of Agriculture, Abeokuta from $3^{\text {rd }}$ to $6^{\text {th }}$ April. Pp $249-256$.

Jamilu, A. A., Atala, T. K., Akpoko, J. G. and Sanni, S. A. (2016) Factors Influencing Smallholder Farmers Participation in IFAD-Community Based Agricultural and Rural Development Project in Katsina State. Journal of Agricultural Extension, 16(2): 93-105.

Kishi, M. (2005). The health impacts of pesticides: What do we know? The Pesticide Detox (J. Pretty), London. 263p.

Kishi, M., Hirschon, N., Djajadisastra, M., Satterlee, L. N., Strowman, S. and Dilts R (2005). Relationship of pesticide spraying to signs and symptoms in Indonesian farmers. Scandinavian Journal of Work and Environmental Health 21(2): 124-133.

Kughur, P. G. (2012). The effects of herbicides on crop production and environment in Makurdi Local Government Area of Benue State, Nigeria. Journal of Sustainable Development in Africa, 14(4): 23-29. 
Creative commons User License: CC BY-NC-ND

Abstracted by: EBSCOhost, Electronic Journals Service (EJS),

Google Scholar, Directory of Open Access Journals (DOAJ),

Journal Seek, Scientific Commons,

Food and Agricultural Organization (FAO), CABI and Scopus
Journal of Agricultural Extension

Vol. 21 (1) February, 2017

ISSN(e): 24086851; ISSN(Print); $1119944 X$

http://journal.aesonnigeria.org

http://www.ajol.info/index.php/jae

Email: editorinchief@aesonnigeria.org

Laary, J. K. (2012). Dry-season farming and agrochemical misuse in upper east region of Ghana: Implication and way forward. Journal of Agricultural, Food and Environmental Sciences, 5(1): 17-26.

Lomborg, B. (2001). The Skeptical Environmentalist. Cambridge University Press; Reprint edition August 28, ISBN: 0521010683

Mariyono, J. and Bhattarai, M. (2010). Factors determinant of pesticides use in chili pepper farming in Central Java, Indonesia, Agricultural System Journal. 12(2): 44-56.

Meenambigai, J. and Seetharaman, R. N. (2003). Training needs of extension personnel in communication and Transfer of technology. Agricultural Research and Extension Network Newsletter No 48; pp 19.

Meijden, G. V. (1998). Pesticide application techniques in West Africa. A study by the Agricultural Engineering Branch of FAO through the FAO Regional Office for Africa. 17pp.

Mokwunye, I. U., Babalola, F. D., Ndagi, I., Idrisu, M., Mokwunye, F. C., and Asogwa, E.U. (2012). Farmers' compliance with the use of approved cocoa pesticides in cocoa producing States of Nigeria. Journal of Agriculture and Social Research (JASR), 12(2): Pp $44-60$.

Moser, C.M. and Barrett, C. B. (2003). The disappointing adoption dynamics of a yield-increasing, low external-input technology: The case of SRI in Madagascar. Journal of Agricultural Systems, 76(3): 1085-1100.

Namwata, B.M.L., Lwelamira, J. and Mzirai, O.B. (2010). Adoption of improved agricultural technologies for Irish potatoes (Solanumtuberosum) among farmers in Mbeya Rural district, Tanzania: A case of llungu ward. Journal of Animal \& Plant Sciences, 8(1): 927- 935.

National Agricultural Extension and Research Liaison Services and Federal Department of Agricultural Extension (2014). Agricultural performance survey of 2014 wet season in Nigeria, Executive summary. October. Pp 23.

National Agricultural Extension and Research Liaison Services and National Programme on Agriculture and Food Security (2011). National report of Agricultural performance survey of 2010 wet season in Nigeria. December.175 pp.

National Population Commission (2006).Census Report of Nigeria.Population and Development Review,33(1) (Mar., 2007), pp. 206-210 Published by: Population Council Article Stable URL: http://www.jstor.org/stable/25434601 Assessed 7th May 2013. 
Creative commons User License: CC BY-NC-ND

Abstracted by: EBSCOhost, Electronic Journals Service (EJS),

Google Scholar, Directory of Open Access Journals (DOAJ),

Journal Seek, Scientific Commons,

Food and Agricultural Organization (FAO), CABI and Scopus
Journal of Agricultural Extension

Vol. 21 (1) February, 2017

ISSN(e): 24086851; ISSN(Print); 1119944X

http://journal.aesonnigeria.org

http://www.ajol.info/index.php/jae

Email: editorinchief@aesonnigeria.org

Nyatuame, M. and Ampiaw, F. (2015). Assessment of farmers' awareness on the safety and health implications on the use of agrochemicals: A case of Afife rice farm in Ghana. Asian Journal of Agricultural Extension, Economics and Sociology, 7(3): 1-9.

Olabode, O.S., Adesina, G.O. and Olapeju, T.R. (2011).Survey of agricultural chemicals available to farmers in South Western Nigeria. .International Journal of Agricultural Economics and Rural Development, 4 (1):12 - 18.

Rahman, S.A. (2008). Women's involvement in agriculture in Northern and Southern Kaduna State, Nigeria. Journal of Gender Studies, 17(1):17-26.

Rashid, M.A., Alam, S. N., Rouf, F.M.A. and Talekar, N.S. (2003). Socio-economic parameters of eggplant protection in Jessore District of Bangladesh. Technical Bulletin 29.AVRDC - The World Vegetable Center, Shanhua, Taiwan.37 pp.

Tanko, L and Olowogbaji, J. A. (2009). Technical efficiency and the determinants in yam production in Bosso area, Niger State, Nigeria. Food production in a developing economy, 1: 296-303.

Udoh, A. J. (2009). Nigerian farm household hazards. http://www.panuk.org/pestnews/lssue/pn40/pn40p8.htm Assessed 26 ${ }^{\text {th }}$ March, 2015.

Vaagt, G. (2005). International Conventions - Implications to pesticides management, Regional Workshop on the International Code of Conduct, Presentation, www.fao.org/docrep/008/af340e/af340e05.htm. Accessed: 19/04/2012.

Zyoud, S.H., Sawalha, A.F., Sweileh, W.M., Suleiman, R.A., Al-Khalil, I., Al-Jabi, S.W. and Bsharat, N.M. (2010). Knowledge and practices of pesticide use among farm workers in the West Bank, Palestine: safety implications. Pp 15. 